\title{
Evaluation of the Antifungal Effect Vitis vinifera Extract on Candida albicans
}

\author{
Leandro Maciel Uchoa Gadelha', Lídia Audrey Rocha Valadas', Nicole de Mello Fiallos², Sônia Luque Peralta ${ }^{3}$, Keniesd Sampaio Men- \\ donça', Mara Assef Leitão Lotif', Gilvan Lima Bezerra', Márcio Glauber Lopes de Aguiar', Érika Sabóia Guerra Diógenes' , Edilson Martins \\ Rodrigues Neto', George Otávio Asevedo', Ana Cristina de Mello Fiallos ${ }^{1}$ \\ 'Pharmacy, Dentistry and Nursing College, Federal University of Ceara, Fortaleza, CE, BRAZIL. \\ 2Dentistry College State University of Rio de Janeiro, UERJ, Rio de Janeiro, RJ, BRAZIL. \\ ${ }^{3}$ State University of Ceara, UECE, Fortaleza, CE, BRAZIL. \\ ${ }^{4}$ Paulo Picanço College of Dentistry, Fortaleza, CE, BRAZIL.
}

\begin{abstract}
Objective: This research analyzed in vitro the antifungal activity of the solution composed by grapes seed extract Vitis vinifera (Doctor's A-Z®) against Candida albicans (ATCC 20231) species aiming to determine the minimum inhibitory concentration (MIC) and minimum fungicide concentration (MFC). Methods: To that, were used micro dilution boards of 96 wells where the strain of Candida. Was tested the diluted solutions in distilled water on the concentrations $0.20 \mathrm{~g} / \mathrm{mL}$, $0.30 \mathrm{~g} / \mathrm{mL}$ and $0.40 \mathrm{~g} / \mathrm{mL}$. As growing control were used growing fungous, to test the viability of the strains. As positive control, was used nystatin (commercial suspension 100,000 $\mathrm{UI} / \mathrm{mL}$ ) and as sterility control of growing way. The tests were conducted in triplicate and the data obtained were analyzed through the exam Kruskal-Wallis, with significance level of $95 \%(p<0.05)$. Results: The results indicated that all the samples were sensible to the analyzed extract and the CIM was obtained with the solution of $0.30 \mathrm{~g} / \mathrm{mL}(30 \%)$. However, wasn't observed a fungicide
\end{abstract}

effect (MFC) on the tested concentrations. Conclusion: We conclude that the grapes seed extract can be an alternative against the gender Candida, however are necessary larger studies to prove their ant fungous action.

Key words: Grapes seed extract, Stomatitis under prosthesis, Candida albicans, Dental prosthesis.

Correspondence :

Mara Assef Leitão Lotif, 1210 Capitao Francisco Pedro, Fortaleza-Ce-Brazil, ZipCode 60430370, BRAZIL.

Phone: +558533668000

Email: mara_lotif@hotmail.com

DOI: 10.5530/jyp.2018.10.37

\section{INTRODUCTION}

Fungous of the type Candida are frequently common and are part of the normal microbiota of the human organs and can be isolated on the most diverse anatomic places; about 20 to $50 \%$ of the healthy toothed present colonization by Candida. ${ }^{1,2}$ It is known that the species of the gender Candida, live in a dynamic equilibrium (commensalism) with the host. However, when this harmony is disrupted, can occur diseases that can be from a local inflammatory manifestation till systemic ringworms that can lead the individual to the death and the terms candidiasis or candida are applied to design infectious processes caused by those fungous. ${ }^{3}$

From the many options of treatment to the partial list of teeth is the removable partial prosthesis and gramps (RPPGs). This prosthetic modality consists in one of the most searched solution due to its therapeutic satisfactory and accessible cost to a huge part of the population. However, the deficient sanitation and the lack of maintains of those prosthesis are risk factors to oral infections with possible systemic dissemination. This because as for the resins to the prosthesis practice, in high scale, as the metallic components that constitute them can be colonized by many microbial species of the oral cavity, such as bacteria, fungal and virus's species. $^{4,5}$

The oral candidiasis, also called of stomatitis or popularly thrush, is characterized by the appearance of the white plaques, isolated or grouped adhered to the mucous. They have membranous aspects and, sometimes, are surrounded by halo erythematous. On the users with prosthesis, it is called prosthetic stomatitis, atrophic candidiasis or stomatitis by prosthesis. $^{3}$

The prosthetic stomatitis consists in a pathological condition characterized by an inflammatory process that affects the oral mucous about two thirds of the users of prosthesis. Most of the individuals infected are women and elderly and the adherence to the Candida albicans to the prosthesis superficies is the first step to develop this lesion. ${ }^{6}$ Are observed tissues changes, especially on the presence of superior prosthesis, among which are found the lesions on the palate and changes on the soft tissue, accompanied or not for others inflammatory manifestations (angular queilite and glossitis). Furthermore, some patients are presented as asymptomatic to the infection; however, they normally report various symptoms, as pain, swelling, xerostomia, halitosis and bleeding, symptoms that many times impossible the prosthesis use. . $^{4,8}$

The predisposition to candidiasis is favorable by a range of systemic factors that, directly or indirectly, take to an immunossuppression, as: cancer, prolonged antibiotic therapy; xerostomia; innutrition, age (mainly elderly and children); diabetes; AIDS (Acquired Immunodeficiency Syndrome) and pregnancy. However, local factors can also contribute, among them, the smoking; pre-existing diseases on the oral mucous; precarious hygiene and bad use or maintenance of the dental prosthesis. The presence of those events, being isolated or associated, favorable the binomials microorganisms/host, condition where the defenses of the 
individual is compromised, allowing the disordered growing of the fungal and the tissue invasion, characteristic of the opportunist infectious disease. ${ }^{3,4,9,10,11}$

The treatment directed to the prosthetic stomatitis include anti fungous topic therapy, caring with the oral hygiene and hygiene procedures and disinfection of the removable prosthesis. However, this treatment many times is not efficient and recurrences occur after the interruption of the medication use. Studies indicate that a genetic adaption by the fungus microorganisms, causing resistance to some drugs have been observed on the last three decades. In addition, conventional anti fungous present significant toxicity, which shall be took in consideration during the clinical practice. $^{12}$

Bearing in mind those difficulties that interfere on the treatment of the patient with antifungal agents, is very important the study of others efficient medicines substances and with less collateral effect to the patient. Thereby, on the last decades, it is observed an increasing on the natural products for oral hygiene and the prosthesis aiming the prevention of the prosthetic stomatitis. ${ }^{13}$

Natural products are important source to discover new useful substances and different strategies can be applied to improve the productivity of bio active metabolites, to obtain extracts chemically standardized. ${ }^{14}$ The grapes (Vitis vinifera) are one of the most important fruits species of the world, cultivated specially on the Mediterranean area. According to the reported by the wide literature, the grapes are rich sources of polyphenols, important secondary metabolites produced by superior plants, which can develop multiples essential roles in vegetal physiology and show healthily properties on the human organism, mainly as antioxidant, anti-allergic, anti-inflammatory, anti-cancerous, anti-hypertensive, Reno protective agents and anti-microbial. ${ }^{15}$

The vegetal specie Vitis vinifera, denominated vine or grapevine, cultivated for thousand years, product a very important fruit with great feed and cultural value to the human species: the grape, largely consumed, in natura or in the juices and candies form. The fermentation of the grape juice product an alcoholic liquid, the wine, known since the antiquity. Many compounds have been described on the literature, present on grapes and consequently on wines, which are attributed many pharmacological actions. From then on, the grape and the wine have been studied, more and more, all around the world, and the wine entered to the listed of the functional food, consumed with the finality to prevent diseases and keep the health. ${ }^{16}$

Lately, it is noticed the interest on the grape seed extract (Vitis vinifera) as an antimicrobial and antifungal alternative. Thereby, studies have been conducted to test the action of the seeds of Vitis vinifera. Thus, in vitro, Simonetti et al. (2014) tested the susceptibility of many strains of Candida to the antifungal action of the extract of seed of Vitis vinifera. Those authors also conducted a complementary study, in vivo, in mice, testing the anti-fungus action of extract of the grape seed on the vaginal candidiasis and they should show that the obtained extract from the Vitis vinifera seed, rich in flavonoids, presented a high anti fungus effect in both experiments. ${ }^{17}$

Those findings suggest that the extract obtained from the Vitis vinifera seeds, by its antifungal effect, can be an alternative to the treatment in infections by Candida albicans associated to prosthetic stomatitis and/ or sanitation of prosthetics superficies. However, the analysis of the literature verified that is not well established yet the inhibitory minimal concentration efficient against the principal species of Candida involved on the prosthetic stomatitis development, aiming to determine its minimum inhibitory concentration (MIC) and minimum fungous concentration (MFC),

\section{METHODS}

It was conducted a study of inductive approach, with a comparative statistic and procedure with direct documentation in laboratory.

The microbiological tests were conducted at the Research Laboratory in the Pharmacy, Dentistry and Nursery College from the Federal University of Ceara. It was used strains of the fungus from the Candida albicans specie (ATCC 20131) available by the laboratory.

The microorganisms were reactivated in broth Sabourad-Dextrose (KASVI ${ }^{\star}$, Italy) and sucrose 1\% (DINAMIC •, Diadema, São Paulo, Brazil), in $37^{\circ} \mathrm{C}$ per $24 \mathrm{~h}$. To the study conduction, fungous suspensions of the microorganisms were prepared in salt solution $0.9 \%$ (SYNTH , Diadema, Sao Paulo, Brazil), under the concentration $1.5 \times 10^{6}$ microorganisms $/ \mathrm{mL}$, equivalent to the tube $10^{6}$ from the MacFarland scale.

To the antifungal evaluation in vitro, was used extract of the seed of grapes Vitis vinifera, commercial form Doctor's A-Z ${ }^{\bullet}$, distributed by DOCTOR'S A-Z, PO Box 2803, Fargo, ND, 58108, USA. Pharmaceutical form of presentation of $100 \mathrm{mg}$ pills, packs with 60 pills. Each pill contained dry extracted of the Vitis vinifera seed, $100 \mathrm{mg}$ (Standardized in $90 \%$ of flabonoids). Excipients: dust mixing of grapes seed and shell, jelly and rice flour. The substance to be tested was under the expiration date informed by the fabricant.

The Vitis vinifera extract used in this study was diluted initially in sterile distilled water. To the fungus action evaluation, was conducted the serial dilution technique according to the reference document NCCLSM27A2, ${ }^{18}$ adapted to the compound. ${ }^{19}$ Was obtained solutions of $0.20 \mathrm{~g} / \mathrm{mL}$, $0.30 \mathrm{~g} / \mathrm{mL}$ and $0.40 \mathrm{~g} / \mathrm{mL}(20 \%, 40 \%$ and $40 \%)$.

The tests were composed by six groups. Group 1 Vitis vinifera at $20 \%$ (GV20); Group 2 Vitis vinifera at 30\% (GVV30); Group 3 Vitis vinifera at 40\% (GVV40); Group 4 Growing control (GGC) - composed by fungous Candida albicans growing with broth Sabered-Dextrose, aiming to test the strain viability; the group 5 positive control (GPC) - Nystatin commercial suspension $100.000 \mathrm{Un} / \mathrm{mL}$. (NEOCHEMICALS ^, Anapolis, Goiás, Brazil), aiming to test the susceptibly of the samples before a synthetic antifungal already consecrated by its action; and the group 6 sterility control (GSC) - Compound only by the broth growing form Sabourad-Dextrose, aiming to test the non-contamination through growing and posterior comparison to the other groups.

The test of susceptibility to antifungal by the serial dilution method was conducted in micro dilution plaques with 96 wells (ALAMAR ${ }^{\circledR}$, Diadema, São Paulo, Brazil), disposed in 12 rolls ( 1 to 12 ) in 8 lines (A to $H)$. The lines $\mathrm{A}, \mathrm{B}$ and $\mathrm{C}$ were destined to anti fungous analysis of the Vitis vinifera at $20 \%, 30 \%$ and $40 \%$, respectively. The line D was destined to the growing control; the line $\mathrm{E}$ to the positive control and the line $\mathrm{F}$ to the sterility control.

In each of the microdilution plaque wells were inserted $100 \mu \mathrm{L}$ of the inoculums Candida albicans, except on the correspondent line to the sterility control. After, was inserted $100 \mu \mathrm{L}$ of the solutions of Vitis vinifera at the three first lines, according to each group. To the wells of the line $\mathrm{D}$ and $\mathrm{F}$, were dispensed $100 \mu \mathrm{L}$ and $200 \mu \mathrm{L}$ of half broth Sabourad-Dextrose, respectively, to match the total volume of the wells from the growing and sterility group control. On the fifth line, $100 \mu \mathrm{L}$ of nystatin were added. The plaques were incubated in bacteriological greenhouse at $37^{\circ}$, for $24 \mathrm{~h}$.

Posteriorly was conducted serial dilutions and seeding in agar SabourandDextrose (KASVI ${ }^{\oplus}$, Italy) on aliquots of $10 \mu \mathrm{L}$ of the samples of all the wells, in Petri plaques. After the seeding of the wells contents with microdilution plaques, the petri dishes were incubated in bacteriological greenhouse at $37^{\circ}$, for $24 \mathrm{~h}$. Posteriorly, was conducted the reading of the plaques through counts of the Colonies Trainer Unities (CTU). Per definition, the lower concentration capable to 
produce prominent inhibition (50\%) of the yeast growth in relation to the well control of growth is the MIN (Minimum Inhibitory Concentration) of the drug to this sample. The determination of the MFC (Minimum Fungous Concentration) consists in the minor concentration that stopped the visible growing. ${ }^{20}$

All the tests were conducted in triplicate. The data were tabled on the Microsoft Excel 2013 software (MICROSOFT ^, Redmond, Washington, USA) and the statistical analysis was conducted on the SigmaStat 4.0 software (SYSTAT SOFTWARE INC ${ }^{\oplus}$, San Jose, California, USA), using the Kruskal-Wallis test, with significant level of 95\% ( $\mathrm{p}<0.05)$.

\section{RESULTS}

The results obtained on the tests were represented in table Table 1 and graphic according to the Kruskal-Wallis test Figure 1.

The tested solutions presented fungous activity against the tested strain Candida albicans. For definition, the lower concentration capable to produce prominent inhibition (50\%) of the growth of the yeast in relation to the well growth control is the MIC (Minimum inhibitory concentration) and, in this study, the solution that is more suitable on the description is the $0.30 \mathrm{~g} / \mathrm{mL}(30 \%)$.

Statistically, the solution of Vitis vinifera seed extract in $0.40 \mathrm{~g} / \mathrm{mL}$ (40\%) was like the Nystatin group (positive control). Thereby, this group presented intermediate activity between the growth control and the positive control.

On the present study was not found the minimum fungous concentration (MFC) because was not possible to test higher concentrations by the difficulty to dissolute the compound.

Table 1: Counting of Colonies trainer unity by millimeter.

\begin{tabular}{cc}
\hline Group & Counting Ctu/Ml \\
\hline GVV20 & $13.3 \times 10^{5}$ \\
GVV30 & $7.1 \times 10^{5}$ \\
GVV40 & $3.7 \times 10^{5}$ \\
GGC & $17.4 \times 10^{5}$ \\
GPC & 0 \\
GSC & 0 \\
\hline
\end{tabular}

Label: GVV: Group Vitis vinifera; GCC: Group Growth Control; GCP: Group Positive/ Nystatin control; GCE: Group Sterility control

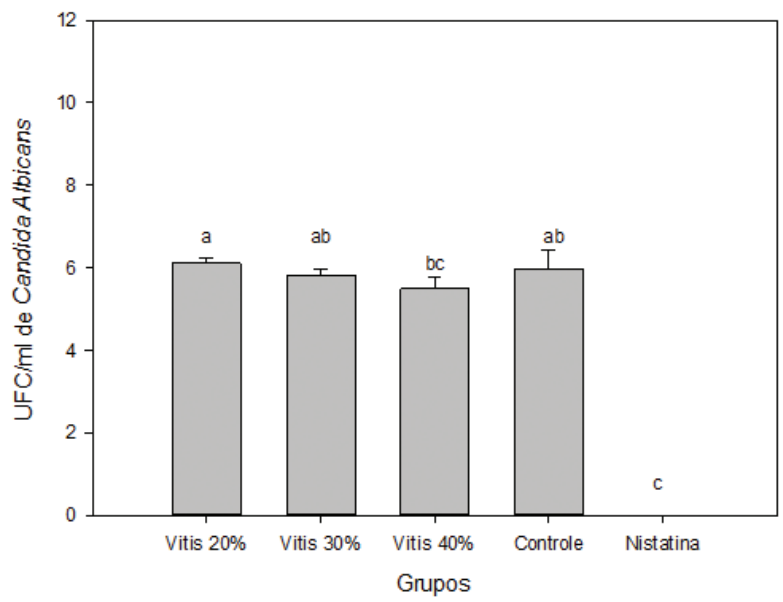

Figure 1: Evaluation of the anti-fungous activity of the Vitis vinifera seed extract against the Candida albicans. Kruskal-Wallis $(p<0.05)$.

\section{DISCUSSION}

The biofilms formation by fungous on prosthesis superficies, as the partially removable prosthesis, is considered critical to the prosthetic stomatitis development. The fungus of the specie Candida albicans are considered the most frequent and main agents etiologic of this lesion. ${ }^{21}$ Thereby, in this present research were evaluated biofilms formed exclusively by those microorganisms.

In the last decades, it became intense the search for therapeutic alternatives with capacity to decrease, eliminate or stop the Candida adherence to the PPRGs, without causing problems to the prosthesis or the user, and of substances capable to acto on the EP repression. ${ }^{22,23}$ In this scenario the natural products emerge as singular promise, seen that many present less toxicity, larger pharmacologic activity and biocompatible, beside more accessible costs to the population. ${ }^{24}$

Per definition, herbal medicines are vegetal preparation standardized that consist of a complex mixed of one or more substances present on the plant where, in most of the cases, the active principle is unknown. It can be presented in many ways, as in a juice, wax, exudates, oil, extract, dye, among others. ${ }^{23}$

On the literature, it is noticed the great interest in new natural actives and herbal medicines, due its antimicrobial properties and/ or antiinflammatory, being, in the last years, many them reported. Among them, it can be found spread describe actives like vinegar from the apple, ${ }^{25}$ black-pepper, ${ }^{19}$ garlic, sage, mastic gum, ${ }^{23}$ melaleuca, rosemary, citronella, ${ }^{20}$ propolis and pomegranates. ${ }^{26}$ As emphasis, it is the grape (Vitis vinifera). The grapes are considered one of the largest source of phenolic compounds when compared to other fruits and vegetables, being mainly composed phenolic monometric, flavonoids oligomerics and proanthocyanidins, substances considered as responsible by its many properties. ${ }^{26,27}$

One of its most studied effects is the antioxidant activity, capacity to face the free radicals and to protect the cell. Studies show that extracts from the grape seed (Vitis vinifera) possesses high antioxidant activity, differing accordingly with the grape phenolic composition. Free radicals are atoms or molecules with non-paired electrons and, for this, attack others molecules to steal their electrons and thus become stable. Compounds from the grape acts in a similar way to the redactors agents through the donation of electrons to the free radicals, turning them into more stable products. The ingestion of those compounds is recommended through food or nutritional supplements. ${ }^{28}$

Vitis vinifera also presents anti-inflammatory characteristics and was described that the topic application of the grape seed extract, rich in proanthocyanidins, promote the wounds healing, regulates positively the tumor necrosis factor (TNF-a) and induct the growth endothelial vascular factor expression (VEGF) in human's keratinocytes. ${ }^{29}$

Studies in vitro were conducted demonstrating susceptibility of some microorganisms to the grape seed extract. Vitis vinifera presented antimicrobial activity against the Bacilluscerus, Bacilluscoagulans, Bacillusubtillis, Staphylococcus aureus, Escherichia coli and pseudomonasareuginosa. ${ }^{28,30}$

Seen the great interest and application in many areas of medicine, Vitis vinifera became object of study of the present worksheet. On literature, there are few studies relating to the species Candida albicans and its antifungous activity, confirming the necessity of studies evaluating the relation Vitis vinifera and Candida, as the present study did.

In pilot studies previously reported, using solutions of the Vitis vinifera grape seed extract with the concentration of $0.05 \mathrm{~g} / \mathrm{mL}, 0.10 \mathrm{~g} / \mathrm{mL}$, $0.20 \mathrm{~g} / \mathrm{mL}(5 \%, 10 \%$ and $20 \%$, respectively), it was noticed that this last had fungous activity. Therefore, to this study, were used solutions of Vitis 
vinifera seed extract in $0.20 \mathrm{~g} / \mathrm{mL}, 0.30 \mathrm{~g} / \mathrm{mL}$ and $0.40 \mathrm{~g} / \mathrm{mL}(20 \%, 30 \%$ and $40 \%)$.

As positive control was optioned by the Nystatin for being an antifungal considered "gold-standard" and the absence of fungous growth before it shows the susceptibility of the samples front of a sympathetic anti fungous. The sterility and growth control, composed through growth and fungous Candida albicans and through growth, respectively, were used aiming to validate the technique used in this study.

Due to the high turbidity preparing the tested solution, it was not possible to use as methodology the micro dilution test, for hinder a visual analyzes secure and direct or through spectrophotometer.

In a study in vitro conducted per Filocamo and collaborators (2015) was described the antimicrobial effect of the juice of one of the variants from the Vitis vinifera, the white grape. Were tested many bacteria grams positive, gram negative and fungous, among them the Candida albicans. The tested substance did not inhibit the Candida spp growth. On the concentrations tested, 2000 to $3.9 \mu \mathrm{g} / \mathrm{mL}$, the value being possible to be $\mathrm{CIM}>2000 \mu \mathrm{g} / \mathrm{mL} .^{30}$

Recently, in a conducted study by Simonetti et al. (2014), was verified that extracts from Vitis vinifera seeds presented high activity anti fungous against many strains of the Candida in vitro and in vivo, in mice. This study tested pure extracts obtained directly from seeds from many variants of the grape and, using the same strain of fungous tested on the present study, were obtained positive results with lower concentrations $(8 \mathrm{mg} / \mathrm{L}) .^{17}$

There are many variants of the Vitis vinifera, in which the phenolic composition differs among them. It is known that, besides the organoleptic characteristics, different on the composition can also explain the different properties and biological answers, the profile of the phenolic compounds doesn't depend necessarily only of the species and variants, being also variable according to the cultivation. ${ }^{27}$

The extract of Vitis vinifera used in this study was composed by more than one mixing of the extract of the grape seed and shell, with vehicle jelly and rice flour (DOCTOR'S A- $Z^{\circledast}$ ). It was observed fungous activity with the CIM of $0.3 \mathrm{~g} / \mathrm{mL}$, value considered high, what puts in question the applicability and sustainability of the analyzed extract. It is believed that the non-utilization of the pure substance can justify the results only of the fungus activity and also, in an elevated concentration in comparison to other studies. ${ }^{17,30}$

Furthermore, the cited study ${ }^{17}$ used ethyl alcohol during its extract processing, in a proportion of $70 \%(\mathrm{EtOH} / \mathrm{H} 2 \mathrm{O} 7: 3 \mathrm{v} / \mathrm{v})$ aiming to evaluate the probable action anti fungous only of the tested compound, on the present study was used only distilled water. It is known that the alcohol presents antimicrobial activity, summing to the Vitis vinifera action, being possible to justify the few found concentrations.

Thereby, it is necessary more studies to affirm the possibility to use the Vitis vinifera seed as antifungal agent, as well as to evaluate its cytotoxicity and bio compatibility through studies in vitro and in vivo, aiming to secure a probable clinical use. In case its use as an anti-fungous be proved, it is possible to conduct analyzes studies of superficies to verify its use as prosthesis cleaning agent, evaluating if there are changes on the acrylic bases, artificial teeth or metal structures of the different prosthetic modalities.

\section{CONCLUSION}

Inside this study limitation, was concluded that the evaluated product presented fungal activity against Candida albicans strain tested (ATCC 10231), with minimum inhibitory concentration of $0.3 \mathrm{~g} / \mathrm{mL}$, not being verified fungous activity.

\section{REFERENCES}

1. Pereira-Cenci T. Avaliação da formação de biofilme de espécies de Candidasobre a superfície de resinas acrílicas para base e reembasamento de próteses removíveis. Piracicaba, 2008. Tese [Doutorado em Clínica Odontológica - área de Prótese Dentária] - Universidade Estadual de Campinas, Faculdade de Odontologia dePiracicaba, Piracicaba. 2008.

2. Oliveira CE. Candida albicans estomatite por dentadura: avaliação da presença do fungo na lesão, na prótese total superior e no sanque. Bauru, 2009. Dissertação [Mestrado Odontologia-área de Patologia Bucal]-Faculdade de Odontologia de Bauru,Bauru. 2009.

3. Dongari-Bagtzoglou A, Kashleva H, Dwivedi P, Diaz P, Vasilakos J. Characterization of Mucosal Candida albicans Biofilms. PLoS ONE. 2009;4(11):e7967. doi:10.1371/journal.pone.0007967.

4. Andrade IM, Cruz PC, Silva CH, Souza RF, Paranhos HF, Candido RC, et al. Effervescent tablets and ultrasonic devices against Candida and mutans streptococci in denture biofilm. Gerodontology. 2011:28(4):264-70. doi: 10.1111/j.17412358.2010.00378.x.

5. Gusmão JM, Ferreira-dos SSS, Neisser MP, Jorge AO, FariaMI. Correlation between factors associated with the removable partial dentures use and Candida spp. in saliva. Gerodontology. 2011;28(4):283-8. doi: 10.1111/j.17412358.2010.00390.x

6. Pellizzaro D, Polyzois G, Machado AL, Giampaolo ET, Sanitá PV, Vergani CE. Effectiveness of mechanical brushing with different denture cleansing agents in reducing in vitro Candida albicans biofilm viability. Braz. Dent. J. 2012;23(5):547-54 doi:10.1590/S0103-64402012000500013.

7. Silva HF, Martins-filho PRS, Piva MR. Denture-related oral mucosal lesions among farmers in a semi-arid Northeastern Region of Brazil. Med. Oral Patol. Oral Cir. Bucal. 2011; 16(6):740-4. doi:10.4317/medoral.17081.

8. Vasconcelos ICS, Sampaio FC, Sampaio MCC, Pereira MSV, Peixoto MHP. Streptococcus mutans in denture stomatitis patients under antifungaltherapy. Rev. Odonto.Ciencia. 2010; 25(21):120-5.

9. Avrella D, Goulart LS. Isolamento de Candida spp. Da mucosa oral de pacientes submetidos ao tratamento quimioterápico. Rev. bras. anal. Clin. 2008;40(3):205-7.

10. De-Rossi T, lozovoy MAB, Silva RV, Fernandes EV, Geraldino TH, Costa IC et al. Interações entre Candida albicans e Hospedeiro. Semina: Ciencias Biologicas e da Saude. 2011;32(1):15-28. doi:10.5433/1679-0367.2011v32n1p15.

11. Favalessa OC, Martins MA, Hahn RC.Aspectos micológicos e suscetibilidade in vitro de leveduras do gênero Candidaem pacientes HIV-positivos provenientes do Estado de Mato Grosso. Rev. Soc. Bras. Med. Trop. 2010;43(6):673-7. doi:10.1590/S0037-86822010000600014.

12. Patton LL, Bonito AJ, Shugars DA. A systematic review of the effectiveness of antifungal drugs for the preventions and treatment of oropharyngeal candidiasis in HIV-positive patients. Oral Surg Oral Med Oral Pathol Oral Radiol Endod. 2001;92(2):170-9. doi: 10.1067/moe.2001.116600.

13. Paiva LCA, Ribeiro RA, Pereira JV, Oliveira NMC. Avaliação clinica e laboratorialdo gel da Uncária tormentosa (Unha de gato) sobre cândidose oral. Rev. bras farmacogn. 2009; 19(2):423-8. doi:10.1590/S0102-695X2009000300015.

14. Tocci N, D'Auria FD, Simonetti G, Panella S, Palamara AT, Pasqua G. A threestepculture system to increase the xanthone production and antifungal activity of Hypericum perforatumsub sp. angustifolium in vitro roots. Plant Physiol Biochem. 2012;57:54-8. doi:10.1016/j.plaphy.2012.04.014.

15. Daglia M. Polyphenols as antimicrobial agents. Curr Opin Biotechnol. 2012;23(2):174-81. doi:10.1016/j.copbio.2011.08.007.

16. Schleier R. Constituintes fitoquímicos de Vitis vinifera. I.(uva). São Paulo, 2004. Monografia [Especialização em Fitoterapia no IBEHE / FACIS] - Instituto Brasileiro de Estudos Homeopáticos. 2004.

17. Simonetti G, Santamaria AR, D'auria FD, Mulinacci N, Innocenti M, Cecchini F. Evaluation of anti-candida activity of Vitis vinifera. L. Seed extracts obtained from wine and table cultivars. Biomed Res Int. 2014.doi: 10.1155/2014/127021.

18. NCCLS. Método de Referência para Testes de Diluição em Caldo para a Determinação da Sensibilidade a Terapia Antifúngica das Leveduras. Norma M27-A2 do NCCLS. Pensylvânia: NCCLS. 2002. ISBN 1-56238-469-4.

19. Karsha PV, Lakshim OB. Antibacterial activity of black pepper (Piper nigrumLinn.) with special reference to its modeo faction on bacteria. Indian J Nat Prod Resour. 2010;1(2):213-5

20. CavalcantiYW, Almeida LFD, Padilha WWN. Atividade Antifúngica de Três Óleos Essenciais Sobre Cepas de Candida. Rev Odontol Bras Central, 2011;20(52):68-73.

21. Alavarce RAS. São Paulo, 2004. Bauru, 2014. Dissertação [Mestrado em Ciências no Programa de Ciências Odontológicas Aplicadas-área de concentração Patologia Bucal]-Faculdade de Odontologia de Bauru, Bauru. 2014.

22. Felipucci DN, Davi LR, Paranhos HF, Bezzon OL, Silva RF, Pagnano VO. Effect of diferente cleansers on the surface of removable partialdenture. Braz Dent $\mathrm{J}$. 2011;22(5):392-7.

23. Machado AC, Oliveira RC. Medicamentos Fitoterápicos na odontologia: evidências e perspectivas sobre o usoda aroeira-do-sertão (Myracrodruonurun de uva Allemão). Rev. Bras. PI. Med. 2014;16(2):283-9.

24. Francisco KSF. Fitoterapia: uma opção para o tratamento odontológico. Rev Saude. 2010; 4(1):18-24. 
25. Mota AC, Castro RD, Araújo-Oliveira J, Oliveira-Lima E. Antifungal activity of apple cidervine garon cândida species involved in denture stomatitis. J Prosthodont. 2015;24(4):296-302. doi: 10.1111/jopr.12207.

26. Casaroto AR, Lara VS. Phytomedicines for Candida-associated denture stomatitis. Fitoterapia. 2010;81(5):323-8. doi: 10.1016/j.fitote.2009.12.003.

27. Abe LT, Da-Mota RV, Lajolo FM, Genovese MI. Compostos fenólicos e capacidade antioxidante de cultivares de uvas Vitis labrusca L. e Vitis vinífera L. Ciênc. Tecnol. Aliment. 2007;27(2):394-400.
28. Jayaprakasha GK, Selvi T, Sakariah KK. Antibacterial and antioxidant activities of grape (Vitis vinifera) seed extracts. Food Res Int. 2003;36(2):117-22. doi:10.1016/ S0963-9969(02)00116-3.

29. Pazyar N, Yaghoobi R, Rafiee E, Mehrabian A, Feily A. Skin wound healing and phytomedicine: a review. Skin Pharmacol Physiol. 2014;27(6):303-10. doi: 10.1159/000357477.

30. Filocamo A, Bisignamo C, Mandalari G, Navarra M. In vitro antimicrobial activity and effect on biofilm production of a white grape juice (Vitis vinifera) extract Evid Based Complement Alternat Med. 2015. doi: 10.1155/2015/856243.

Article History: Submission Date : 14-07-2017 ; Revised Date : 31-07-2017; Acceptance Date : 19-08-2017.

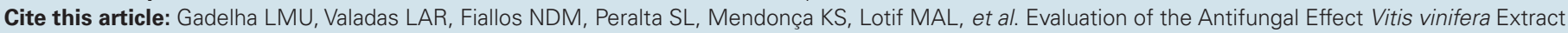
on Candida albicans. J Young Pharm. 2018;10(2):164-8. 